The Bermuda Triangle of Entrepreneurship Education: The Role of Social Networking in

\title{
Entrepreneurial Learning
}

\section{Abstract}

While entrepreneurship education increasingly uses various means to connect students to the 'real world', the impact of social networking on learning remains under-explored. This qualitative study of student entrepreneurs in UK and Sweden shows that their entrepreneurial journey becomes increasingly complex, requiring skills and knowledge not solely developed through formal or nonformal learning. Social networks, and associated informal learning, are shown to be critical in developing social capital important to the students' entrepreneurial journey. This study exposes a key value of social networking and encourages educators to embed activities that facilitate students' informal learning within the curriculum.

Keywords: entrepreneurial learning, entrepreneurship education, social networking, social capital.

\section{Introduction}

Entrepreneurial competence has become a 'hot topic' for both society and academia (Matlay and Carey, 2007; Young, 2014); not least because governments and organisations worldwide consider entrepreneurship a vital part of economic growth (OECD, 2013) and necessary if institutions, like universities, are to educate people to be part of an 'enterprise society' (Cedefop, 2011; European Commission, 2014, 2015; Gibb, 2005). Indeed, in developed countries, such as the UK, the aspiration of young people to start their own business has more than doubled-in recent years (Young, 2014).

For this reason, the enterprising spirit or entrepreneurial orientationdeveloping entrepreneurial competency-of an individual is increasingly seen as critical if individualsthey are to be part of an innovative global labour market; ; it should also encourageit should also encouragebut also encourages "a positive outlook on life that enables [them] to succeed in any endeavour" (Young,

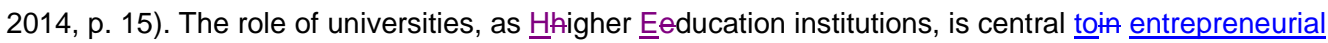
competency development from a learning perspectivethis endeavour (Formica, 2002; Higgins and Galloway, 2014). However, what is the role of universities in supporting the development of

\begin{tabular}{|l|}
\hline Formatted: Highlight \\
\hline Formatted: Highlight \\
\hline Formatted: Highlight \\
\hline Formatted: Highlight \\
\hline Formatted: Highlight \\
\hline Formatted: Highlight \\
\hline
\end{tabular}

Formatted: Highlight 
entreprenourial competengygiven the broad spectrum of education design in regards to entrepreneurship, and the associated lack of conscensus regarding assessment of educational outcomes- (Byrne et al, 2014; Johannisson, 2016; Sirelkhatim \& Gangi, 2015; Slattery \& Danaher, 2015)(Byrne, Fayolle, \& Toutain, 2014; Johannisson, 2016; Sirelkhatim \& Gangi, 2015; Slattery \& Danaher, 2015), universities are challenged in their role of generating entrepreneurially capable individuals. Information, activity and potential learning permeate different spaces within the university environment, spanning from formalized courses with general knowledge about entrepreneurship to specific competency development through creation of new ventures-_Lackéus \& Williams Middleton, 2015)(Lackéus \& Williams Middleton, 2015), to non-formal/extra-curricular student clubs and programs supporting entrepreneurial interests-_(Pittaway et al, 2015),(Pittaway, Gazzard, Shore, \& Williamson, 2015), and to incubators and innovation systems supporting students' entrepreneurial engagement-(Armitage, Jones, Langsam, Manullang, \& Plank, 2011; Lundqvist, 2014; Meyer, Aten, Krause, Metzger, \& Holloway, 2011) (Armitage et al, 2011; Lundqvist, 2014; Meyer et al, 2011). This article explores entrepreneurial learning from the perspective of the student engaging in entrepreneurial activity while attending university, enabling us-enabling us to understand different contributions within the university context. Particular attention is paid to the learning contribution to entrepreneurial competence which could be seen to fall outside formal entrepreneurial education.

This article continues as follows. First, the theoretical framework of entrepreneurial learning and entrepreneurial social networking in universities is summarised. Second, the methodology, including the empirical setting, the sample and data collection, and the data analysis, is described. Next, the $\underline{\text { results for both cases are presented. The discussion and conclusion close the article. }}$

\section{Theoretical framework}

\section{Entrepreneurial Learning in Universities}

The seminal work of Coombs et al- (1973) established a typology of educational programmes (Edwards and Muir, 2005; Honig, 2004): (1) formal education programmes, structured and chronologically graded activities that go from primary school to universities and professional training; (2) non-formal education programmes, organised activities outside the curriculum; and (3) informal education programmes, lifelong educational processes developed through daily life experiences of the 
individual (Knapper and Cropley, 2000; Ngaka et al-, 2012; Sharma and Choudhary, 2015). While this 'educational triad' may be theoretically clear and aimed to help teachers and educators design modules with specific educational objectives, in the context of entrepreneurship situated at the university, the lines between these types of learniglearning are significantly blurred and often unknowingly criss-crossed.____Thus, instead of a well-planned "educational triad', the potential entrepreneurial learning embedded in the university context could seem to be 'Lltost in Sspace', particularly from the perspective of the learner. There are abundant learning opportunities in the university context, but how they connect (or not) is not necessarily clear to the learner, and likely confusing at best.: there is certainly 'something' out there, and some of it is more apparent than others, but how it all connects (or not) is confusing at best. Students are therefore left to first identify and then navigate and make sense of a mixture of formal, informal and non-formal learning spaces available to them during their time at university.-_"

In the university environment, educating people in or for $^{1}$ entrepreneurship is typically based on programmes whose outputs are mainly focused on new venture and job creation or increasing their entrepreneurial mindsetmind-set and spirit (Béchard and Toulouse, 1998; Fayolle et al., 2006; Henry et al., 2005; Smith, 2015).-_-There are continuing improvements focused on theoretical and empirical frameworks for the assessment of entrepreneurship_formal entrepreneurship_education (Naia et al., 2014). University programmes in entrepreneurship are normally considered formal education (1), though increasingly universities aim to (or are expected to, given current policy initiatives) provide or facilitate other aspects of entrepreneurial learning including non-formal (2) and informal (3) processes with more of a focus on interactive and experiential learning (Blackwood et al., 2015; Cedefop, 2011). For example, a student who attends zan entrepreneurship programme gains knowledge and skill from a module involving business planning (formal education)._-_The programme (or perhaps separately through a university alumni network, student-club, or incubator) then invites guest entrepreneurs to speak about their entrepreneurial experience (non-formal education), giving students insight into the entrepreneurial process. The student applieis concepts and insights from these events and interactions with classmates and others in the university environment to his/her own idea,idea or reflection in the current news about successful or failed businesses (informal education). - Interactions

${ }_{1}^{1}$ As this article focuses on entrepreneurial learning for action/practice, it emphasizes entrepreneurship education design for the practice of entrepreneurship, therefore going beyond education about entrepreneurship. -For a review of this distinction, see Neck and Greene (2011)(Neck \& Greene, 2011),

\begin{tabular}{|l|}
\hline Formatted: Highlight \\
\hline Formatted: Highlight \\
\hline Formatted: Highlight \\
\hline
\end{tabular}

\begin{tabular}{|l|}
\hline Formatted: Highlight \\
\hline Formatted: Highlight \\
\hline Formatted: Highlight \\
\hline Formatted: Highlight \\
\hline Formatted: Highlight \\
\hline
\end{tabular}

\section{Formatted: Highlight}

Formatted: Highlight

\begin{tabular}{|l|}
\hline Formatted: Font: (Default) Arial, $8 \mathrm{pt}$ \\
\hline Formatted: Justified \\
\hline Formatted: Font: (Default) Arial, $8 \mathrm{pt}$ \\
\hline Formatted: Highlight \\
\hline Formatted: Highlight \\
\hline Formatted: Highlight \\
\hline Formatted: Font: (Default) Arial, $8 \mathrm{pt}$ \\
\hline Formatted: Font: (Default) Arial, $8 \mathrm{pt}$ \\
\hline
\end{tabular}


can be both formally designed as part of curriculum or independently generated by the student him/herself. However, the educational objective of a programme may be difficult to assess when elements of non-fomralformal and/or informal education are included (Skule, 2004), as they may not be integrated into the designed learning outcomes of the programme.-_Also, it can be challenging for educators be certain from where learning is gained - if it is the planned activities of the programme, or serendepitousserendipitous events_(Williams Middleton \& Donnellon, 2014)_(Williams Middleton \& Donnellon, 2014).

With the unique educational objective of developing entrepreneurial capabilities, an entrepreneurship programme may require formal, non-formal and informal education activities to deliver the desired learning outcomes (Edwards and Muir, 2005; Honig, 2004). This increased complexity makes the assessment of the achieved learning objectives difficult. Perhaps for this reason, there are few studies that examine the relationship between the exposure to entrepreneurship education and the consequential entrepreneurial behaviour and competence of the student (Pittaway and Cope, 2007).

Attempts to achieve entrepreneurial impact is sometimes Achieving impact through entrepreneurship education is commonly-approached by delivering non-formal education-trainingprogrammes, typically involving nascent entrepreneurs or entrepreneurs with continuing professional development needs (e.g. Ibrahim and Soufani, 2002; Karlan and Valdivia, 2011; Klofsten, 2000)._For example, in the case of the UK, two relevant programmes were developed. In 2004, the Lancaster LEAD (Leading Enterprise and Development) programme trained small business owners-managers on their leadership skills for 10 months; half of the survey respondents stated an average growth rate of $3.5 \%$ a year (George, 2013). In 2010, the 10,000 Small Businesses UK programme was offered to small business owners in the areas of Birmingham, Leeds, London and Manchester; its application had a significant positive impact on accelerating business growth with participants growing at between $23 \%$ and $42 \%$ per year (Goldman Sachs, 2014).

Most of the studies that explore the impact of entrepreneurship education programmes in universities use proxy variables such as satisfaction (Cruz et al-, 2009), attitudes (von Graevenitz et al., 2010; Lackéus and Williams_-Middleton, 2015) and/or intentions (Piperopoulos, 2012; Souitaris et al-, 2007). The complexity of analysing the relationship between entrepreneurship education at universities and entrepreneurial behaviour competence means that this relationship is barely proven (Matlay, 2008), which thus highlights an important gap in the entrepreneurship literature, and may explain why there
Formatted: Highlight

Formatted: Highlight

Field Code Changed

\section{Formatted: Highlight}

Formatted: Highlight

Formatted: Highlight

\begin{tabular}{|l|}
\hline Formatted: Highlight \\
\hline Formatted: Highlight \\
\hline Formatted: Highlight \\
\hline
\end{tabular}

Formatted: Highlight

Formatted: Highlight

\begin{tabular}{|l|}
\hline Formatted: Highlight \\
\hline Formatted: Highlight \\
\hline Formatted: Highlight \\
\hline Formatted: Highlight \\
\hline Formatted: Highlight \\
\hline Formatted: Highlight \\
\hline
\end{tabular}


is little research analysing the relationship. For instance, the European Commission (2012) analysed various universities in order to examine the impact of entrepreneurship studies on their alumni; $16 \%$ of the entrepreneurship alumni were self-employed in comparison with $10 \%$ of non-entrepreneurship alumni. Hill's (2011) work, on the other hand, analyseds the impact of MBA entrepreneurship education programmes in Ireland; reporting that of the $27 \%$ of MBA graduates who founded ventures after completing the programme, $69 \%$ did not consider the programme as the main reason for their entrepreneurial behaviour and competence. Given that we have not been able to prove whether or not entrepreneurship education programmes are central to increasing entrepreneurial capabilitiescompetences, more research is needed to better understand from where university students acquire these entrepreneurial competences (Matlay and Carey, 2007; Young, 2014), and the role of the university in its acquisition.

It is clear that for entrepreneurship education programmes to have a direct and positive impact on entrepreneurial behaviour and capabilitiescompetences, there is a need for deeper understanding of the formal, non-formal and informal learning elements. Considering Gupta and Bharadwaj (2013), business schools' pedagogical model needs to be reconsidered because entrepreneurship goes beyond business schools: it is a university competence with interdisciplinary possibilities (Gibb et al:, 2013; Janssen et al-, 2007).

Interdisciplinarity is not the only change that needs to be considered if business schools are to adapt to reality. The focus on the individual's participation in education programmes needs be refocused on the type of learning undertaken (Gupta and Bharadwaj, 2013; Higgins and Elliott, 2011; Pittaway et al., 2011; Rae, 2010) and the existence of teachable and non-teachable entrepreneurship elements (Rae and Carswell, 2001; Shepherd and Douglas, 1997). In addition, should, "inclusive, lifelong approach to enterprise and entrepreneurship learning" (informal) be considered as an alternative to traditional (formal) entrepreneurship education programmes? (Rae, 2010, p. 600). Students require an understanding of education as a learning process whether it be formal, non-formal or informal. Entrepreneurial learning is "concerned with how people construct new meaning in the process of recognising and acting on opportunities, and of organising and managing ventures" (Rae and Carswell, 2001, p. 153). This new vision demands new frameworks that help educators to identify and explicit entrepreneurial learning (Man, 2007) because "the recognition of non-formal and informal
Formatted: Highlight

Formatted: Highlight

Formatted: Highlight

Formatted: Highlight

Formatted: Highlight

\begin{tabular}{|l|}
\hline Formatted: Highlight \\
\hline Formatted: Highlight \\
\hline Formatted: Highlight \\
\hline Formatted: Highlight \\
\hline Formatted: Highlight \\
\hline
\end{tabular}

Formatted: Highlight

Formatted: Highlight 
learning outcomes may increase the number of graduates" (Werkins, 2010, p. 17) and their

Formatted: Highlight entrepreneurial eapabilitiescompetences.

This holistic approach allows us to take into account all types of learning environments, both inside and outside the curriculum and across the university, by considering the entrepreneurial journey as a path to develop an individual's long-life entrepreneurial learning. To solve the proposed metaphoric mystery of the being 'Bermuda TriangleLost in Space', it is time to change the focus of research: from business schools to universities, from entrepreneurship education to entrepreneurial learning. it may be useful to change the focus of research from entrepreneurship education to entrepreneurial learning, and from being situated in business schools to occurring across the entire university environment. Stemming from this, our first research question is: How does entrepreneurial learning develop before, during and after students' involvement in universities? (RQ1).

\section{Entrepreneurial Social Networking in Universities}

Entrepreneurship has been recognised as an economic activity embedded in society (European Commission, 2015; OECD, 2013). This has led to the identification of social networking and social capital as being important for business development (Cope et al., 2007; Eagle et al., 2010; Light and Dana, 2013; Stam et al., 2014; Westlund and Adam, 2010) and for the success of the new venture (Aldrich and Zimmer, 1986; Anderson and Jack, 2002; Birley, 1985; Jack, 2005; Jack, 2010; Jack et al, 2010).

Even though social capital and entrepreneurship has been a research topic since the 1980's (Aldrich and Zimmer, 1986; Granovetter, 1985), their inter-relationship attracts increasing attention (Chen et al., 2015; Estrin et al., 2013; Stam and Elfring, 2008). For instance, Anderson et al. (2007) interviewed 10 British entrepreneurs from technological firms; their results suggest-found that social capital "resides in the [entrepreneurial] network as connections and interactions that take place between individuals" (p. 264). Bauernschuster et al. (2010) stated that the propensity to be an entrepreneur is increased when s/he gains access to social capital via club memberships of small German communities. Westlund et al: (2014) proved that entrepreneurial social capital is a determinant for Swedish new firm creation, with more influence in rural areas.

\begin{tabular}{|l|}
\hline Formatted: Highlight \\
\hline Formatted: Highlight \\
\hline Formatted: Highlight \\
\hline Formatted: Highlight \\
\hline Formatted: Highlight \\
\hline Formatted: Highlight \\
\hline Formatted: Highlight \\
\hline Formatted: Highlight \\
\hline Formatted: Highlight \\
\hline Formatted: Highlight \\
\hline Formatted: Highlight \\
\hline Formatted: Highlight \\
\hline Formatted: Highlight \\
\hline Formatted: Font: Italic \\
\hline Formatted: Highlight \\
\hline Formatted: Highlight \\
\hline Formatted: Highlight \\
\hline Formatted: Highlight \\
\hline Formatted: Highlight \\
\hline Formatted: Highlight \\
\hline Formatted: Highlight \\
\hline Formatted: Highlight \\
\hline
\end{tabular}


ThereforeHowever, for an entrepreneurial network to be considered as providing social capital, the network must add value for the nascent entrepreneur (Foxton and Jones, 2011). That is, it must consist of individuals, groups and organisations that support, advice or finance the entrepreneur.'-s growth (Bosma et al., 2004; Casson and Della Giusta, 2007; Kim and Aldrich, 2005). Besides, the entrepreneurial social capital is critical to the perseverance through the entrepreneurial journey, as supported by the principles of effectuation (Sarasvathy and Dew, 2005). Given its importance, it an may be useful be important to understand how an entrepreneurial network can be initiated and what possibilities there are for the emerging or nascent entrepreneur to learn about creating and managing networks in order to develop social capital.

Some entrepreneurship education programmes have been using entrepreneurs to connect students to the 'real world', providing them with an initial network of entrepreneurs and the skills to develop their own network (e.g. Gordon et al., 2012; Lans et al., 2011), although few studies provide results of their impact. For example, six months after the 10,000 Small Businesses UK programme application, $43 \%$ of the participants reported significant change in their business relating to their enhanced business network (Goldman Sachs, 2014). However, like the LEAD programme (George, 2013), the participants are already running growing businesses or social enterprises that meet the selection criteria of the programmes but they cannot be considered as nascent entrepreneurs.

Obviously, not all entrepreneurs with an entrepreneurial network attended an entrepreneurship education programme (e.g. Dawson et al-, 2011; Jack et al-, 2010; Saunders et al-, 2013), which thus requires the-consideration of where and how they formed their network (social networking) and subsequent social capital. This leads us to our second research question: How does entrepreneurial social networking develop before, during and after students' involvement in universities? (RQ2).

In addition, most of the entrepreneurship education programmes view entrepreneurial networks as non-formal education activities (e.g. enterprise society meetings, entrepreneur clubs, entrepreneurial guest speakers and enterprise awards) separate from the curriculum. However, the type of learning generated within these activities corresponds to informal learning. It looks like the 'Bermuda Triangle' is still evident, because aAs much as universities design and deliver activities outside the curriculum to provide students with an initial network of entrepreneurs, the learning acquired to become a successful entrepreneur goes beyond these planned activities and comes additionally from unplanned activities.- Thus, in the university setting, there is a need to investigate In the context of universities,
Formatted: Highlight

Formatted: Highlight

Formatted: Highlight

Formatted: Highlight

Formatted: Highlight

Formatted: Highlight

Formatted: Highlight

Formatted: Highlight

Formatted: Highlight

Formatted: Highlight

Formatted: Highlight

Formatted: Highlight

Formatted: Highlight 
the noed to investigate-the complex and interdependent activities of formal, non-formal and informal entrepreneurial learning and the role of social networking-is now compelling, as this learning is not necessarily obvious either to the learner, or to the educator/facilitator of that learning.-_For this reason, our third research question asks: Is it possible to establish a relationship between students' entrepreneurial social networking and entrepreneurial learning in universities? (RQ3).

1

\section{Methodology}

Gaps identified by the literature review helped to build three research questions. Thise article aims to explore the relationship between the role of social networking and entrepreneurial learning by investigating the entrepreneurial journey of student and graduate entrepreneurs. We utilized Thus, we followed-an interpretive epistemological perspective underpinned by a qualitative research approach, which allowed us to understand the lived experiences of the interviewed entrepreneurs (Gephart, 2004). A life history technique was chosen to facilitate a reflexivity process for the interviewed entrepreneurs the respondents-in order to help them theorize and explain the past, present and future of their entrepreneurial journey (Cassell and Symon, 2004).

Formatted: Highlight

\section{Empirical Setting}

This study involves student and graduates entrepreneurs of two European universities (University of Leeds, UK and Chalmers University of Technology, Sweden) as part of a pilot stage of a wider research project. These two institutions were chosen due to their specific entrepreneurship education programmes. As mentioned, it is important to consider that entrepreneurship can be learned through formal, non-formal and informal educational programmesprocesses; Leeds and Chalmers universities are two different higher education institutions that provide two different types of education in entrepreneurship.

The University of Leeds (Leeds) is one of the biggest universities in the UK and is a member of the Russell Group. Leeds focuses on entrepreneurship to develop: 1) opportunities provided by Leeds University Union (e.g. societies, competitions, work experience, social enterprise); 2) education through Leeds Enterprise Centre (LEC); and 3) support offered by Spark start-up services, business incubation programme, and scholarships and awards. LEC was the focal point for enterprise 
education and research on the campus and contributor to the GOLD standard awarded by the Small Business Charter in 2014. LEC offered a wide range of undergraduate and graduate modules available about enterprise and entrepreneurship skills, such as enterprise and innovation discovery theme-and the Enterprise placement year. In 2013, LEC taught 1,203 students in 2014/15 and launched the MSc Enterprise, 42 students have graduated so far. In addition, Spark engaged with 885 students and supported 48 start-ups in 2014/15 (University of Leeds, 2015).

Chalmers University of Technology (Chalmers), based in Gothenburg (Sweden), is a technical university described as an entrepreneurial university (McQueen and Wallmark, 1982, 1984). Chalmers School of Entrepreneurship was created to offer an entrepreneurship education masters programme in 1997. Currently, the school is combined with the university's incubator, and offers a two-year master programme in 'Entrepreneurship and Business Design'. The design of the school involves: 1) a master-level programme on technology-based entrepreneurship and business development; 2) an incubator managing the recruitment of ideas for incubation (often from institutional researchers), providing business advice/council, and financing initial seed-investment forinte the ventures; 3 ) formation of a venture team made of a student team and a role-set of associated shareholders and stakeholders; and 4) access to an entrepreneurial network including alumni, researchers, professionals, investors, etc. operating within a regional/national innovation system (Lundqvist and Williams-_Middleton, 2008). In the final "'-incubation"- year, students start working with an early-stage technological idea and systematically go through a venture creation process (Lackéus and Williams_-Middleton, 2015), with the ultimate goal of incorporation, should the venture prove to be commercially viable. Students are supported by a network of stakeholders and shareholders. From its start in 1997 to 2015, Since 1997,-more than 450 students have enrolled on the programme, creating more than 80 ventures incorporated-with $80 \%$ of them surviving.

\section{Sample and Data Collection}

Criterion sampling was used (Neergaard and Ulhoi, 2007) with the following criteria used to select Formatted: Highlight individuals to interview: 1) have or are engaged in some entrepreneurial activity; 2) are a final year student or have been-recently graduated from some degree or master-of the selected university. Through these criteria, we ensured that research questions could be answered. 
Three entrepreneurs were interviewed from each university; in total, six entrepreneurs formed the sample. The sample could be considered small, as mentioned in the limitations of the study, regarding its potential generalizability. However, as this study is part of a pilot stage of a wider research project, the sample was considered as enough to provide the initial necessary empirical evidence. The interviews were conducted by two researchers, one at each institution, and audio recorded. On average, interviews were 45 minutes long. In order to follow a life history technique (Cassell and Symon, 2004), an unstructured interview (Creswell, 2013) was used to deepen understanding about each entrepreneurs' journey. No script was prepared but the interviewer had a clear awareness of what topics needed to be discussed, based on the theoretical framework. Interviews started by asking about the first entrepreneurial activity in which the interviewee was involved (even if it was in school); including the people related to that activity (family and friends support, suppliers, customers, etc.) and the knowledge needed to develop it (and where and how this knowledge was acquired). The researcher concluded by asking about interviewee's motivations for engaging in that activity. This process was followed for each entrepreneurial activity that the interviewee had ever engaged with, considering them as critical incidents (Deakins and Freel, 1998). At the end, the researcher asked about each interviewee's future in terms of professional career development.

\section{Data analysis}

The interview analysis process involved the following steps. Firstly, story lines were drawn for each entrepreneur. This helped us to visualise their entrepreneurial activities in a timeline (Figure 1 and Figure 2). Secondly, we then looked for patterns and commonalities among interviews for each institution; this process established categories and themes to explain the situations of the entrepreneurs (McKeever et al-, 2015). This data was then analysed against these themes. Each entrepreneur was used as the unit of analysis to generate a better understanding of their processes. 


\section{Results}

In this sectionsection, we present data fromef each entrepreneur according to their institution, and then, in the discussion section we analysed them against our proposed research questions. This division in universities offers a detailed understanding of their life history, developed in different contexts (universities). For this reason, story lines are presented (Figure 1 and Figure 2) which show entrepreneurial activities as critical incidents.

\section{Leeds case}

\section{INSERT FIGURE 1 HERE}

\section{A-Leeds (AL)}

AL started engaging in entrepreneurial activities when he was 12 years old; he did not develop a formal business structure even though his motivation was purely economic, "I didn't do it particularly because I needed to ... it was an easy and quick way to make money as a kid". He had the support of his parents but his prior knowledge about entrepreneurship and running a business was very limited: "I used that information ... and then I applied it so I could get a better deal". He engaged in both enterprises on his own.

During this initial stage, he was also performing in a band and on his own although he did not identify these activities as running a business, because "it's been just a hobby ... I was just happy that I was earning some money."

After these enterprising experiences, he enrolled ㅇin an undergraduate Management degree because "I always had the idea of having, running, my own business and being self-employed". At that time, he also used the resources provided by Spark to "gave me specific knowledge besides my degree. I thought it was complementary". He also used online resources as part of his informal learning process.

When he finished the Management degree, he enrolled on an MSc Enterprise because he wanted:

"To develop that knowledge and the practical nature of it [running a business]... I was a little bit disappointed with the outcome from my degree, from the academic point of view. I wanted to correct that ... It was also deliberate to use it to meet other people." 
In that programme he met R-External with whom he developed a guided day-trip excursions company. Before launching the business, they sought the advice and views of their friends about the idea asked their friends what they thought about the idea-and, along with the knowledge gained at the Masters and the help from guest speakers and professors, they submitted a business proposal to Spark, winning a scholarship worth $£ 5,000$. However, the motivation was more out of necessity:

"itlt was that [starting a business] or a job ... I was doing pianist work at that time but it was not enough so I needed to do something ... it was also a deliberate career choice."

At this point, his network becomes more formal, including investors and advisors, which allowed him to leave his position in the business and to engage in other projects that he thought could help him to develop a broader network and gain knowledge so he needed to start his own high-tech business in the future.

J-Leeds (JL)

The entrepreneurial activity of $\mathrm{JL}$ started at age 14 mostly supported by an intrinsic motivation and to a lesser extent a desire to make making-money:

"I really enjoyed it, with computers you can do stuff ... you can play around with the designs and the business side, get money in..."

Nonetheless, he sometimes needed help, so he relied on a friend to help him with some clients: "It wasn't 50/50, I was doing the main thing and [my friend] helped me out with some clients". This association became more formal when he was 16 years old due to increasing demand for his designing of websites.

During this first entrepreneurial adventure, his knowledge about how to run a business was provided by his parents in an informal way; indeed, JL's parents "have also had an entrepreneurial mind-set" so he learned from them what he needed to know. According to $\mathrm{JL}$, even though he did business and economics studies at A-level, he "didn't pick up anything especially helpful".

$\mathrm{JL}$ enrolled onin an undergraduate Medicine degree. When exams started during his first year, $\mathrm{JL}$ and another student developed a platform with key multiple-choice questions about medicine modules to help students to-revise; however, having a collaborator "was not part of the plan, we were friends and we were together at that time so we sort of came up with the idea of sending questions". 
In JL's second year, he and O-External did not actively work on the company. Thus, when B-External and S-External offered him to join their business, he negotiated his role. He accepted the offer because "it just sounded interesting, it was a technical challenge". In fact, this new business allowed him to learn from a formal source, although he was not aware of it at that moment:

"I gained lots, in terms of contacting Spark and realising that they were out there ... an appreciation of a business sense ... I didn't know what Angel meant before that ... they introduced me to some start-up businesses."

Looking back, JL feels that "I wish I had actually [enrolled in some formal learning about enterprise or business] because I would have better appreciation for some add value of what I was doing". The network JL developed with this undertaking was more formal; he met academics and Spark people, as well as attending networking events. ButHowever, the necessity need for a of having a network is something that he realises now because there are things that he cannot do by himself. This is reflected in his knowing that he needed a network "happened unconsciously". ButHowever, "in the past few months [I realised that network] is quite big and something that you need ... meeting new people and getting in touch with other people".

$\mathrm{JL}$ abandoned this collaboration with the company because it as-expanded to London and he wanted to finish his medical studies. During this exit, and before going back to the multiple-choice questions company, JL intercalated his medicine degree with a Health Informatics masters. Meeting people, advisors or entrepreneurs introduced by Spark, related to this field has allowed JL to acquire enterprise skills and solve specific problems. It has also provided the opportunity to extend his network and build social capital for the future.

He knew his strengths and weaknesses so he does not mind delegating; this is the reason why "since a month ago, we're taking on some new people, there're people coming on board to share the workload". Because for JL his business is not about "getting money but [looking for] someone willing to be part of it". Having a bigger crew will help $\mathrm{JL}$ to graduate from medicine and expand the company.

\section{E-Leeds (EL)}

When EL was 16, she started her entrepreneurial journey "just to make money. It was kind of accidental, I would just start selling things and I realised that actually I was good at making money". 
Her first attempt at being entrepreneurial was completely by herself, although her family supported her. Because of it, EL thinks thatthinks, "being entrepreneurial is natural. I don't think is something you can teach. I think you can learn about things as you go. You make mistakes and you learn from them", which is the reason why she did not attend any formal education programme to learn how to be entrepreneurial.

Nonetheless, EL affirms that going to university allowed her to do entrepreneurial activities and that is what brought EL to enrol in a Broadcasting degree. The undergraduate programme allowed EL to study two topics: media and English. At the same time, EL engaged in various activities related to her studies: writing a blog about fashion, developing a YouTube channel about fashion linked to her blog, and reporting the London Olympic Games of 2012. These different activities were a combination of her degree and her entrepreneurial spirit.

A year later, EL started her own business with her brother, because "I wanted a good revenue from the industry, control it myself, grow it myself and I always wanted to work for myself rather than for anyone else"; more precisely, "I came with the idea because I run an online blog which is successful with young females so I decided to find a gap in the market and get them think they can't get it anywhere else online". Her brother's role was essential to help her to develop the fashion online shop, she could not do it by herself and needed his skills so "we brought our skills together and we were able to learn from each other". This link to the social context and the social capital that resided within this family relationship was critical to EL.

In relation to her training in being an entrepreneur, EL states that:

"theThe only course l've ever done is with Spark at Leeds Uni, and it was kind of a business boot camp. I learned a lot about that, but more than anythinganything, they just inspired me. I definitely think in business you just have to be inspired and motivated and you just learn the skills".

She also met a lot ofmany young people alike to-her there and advisors with whom she is still in contact weekly. ButHowever, although she thinks that being an entrepreneur can be learned by doing, she realised that: 
"I wouldn't say it's completely natural. Obviously Obviously, you need to understand finance and things like that but you can pay for an accountant, and you can learn this kind of things. Very much it was kind of a natural entrepreneurial spirit, which means you just need to set it up and go alone with that".

Currently, she is expanding the online shop whichshop, which needed more people on board, so her lastest relative addition was her mother, again showing the relevance of social context but in the case of EL especially the family bond: "my mom is actually a part of the team now. She thinks it's great, she's very excited". In fact, she has three people working for her "who help with the marketing and the $P R$ and the social media" expanding her formal network. 


\section{Chalmers' case}

\section{INSERT FIGURE 2 HERE}

D-Chalmers $(D C)$

DC grew up in a community outside of Gothenburg Sweden, known for its entrepreneurial activity. His motivation was from a shared interest among friends -"we just decided we wanted to do something together (...) [we were] all interested in starting our own company"- but the inspiration and support came from DC's mother. The samples of flatbread (Swedish recipe) were readily accepted amongst local restaurants; we "went to Gothenburg and the finest restaurants and asked if they wanted to buy from us and the response was very good". However, the business, started at the age of 21, was not enough to live on.

DC's lack of experience regarding this first business included naivete about general practice. For this reason, DC and his friends ended up switching bakeries to produce their bread, but the original bakery was able to continue selling flatbread based on the recipe given to them by DC.

The next entrepreneurial company was started "together with one of my classmates in Industrial Engineering and Management", during his bachelor studies at Chalmers (25 years old), when "we started a company selling racket bags for tennis and squash". With a bag design in place and initial interest from potential customers, DC and his classmate investigated ways to manufacture the bag. FirstFirst, they used Google: "we googled 'import to Sweden"”. They also visited a trade fair where they were able to get a lotmany of their questions answered, but nonetheless, it still felt like a big risk to use foreign manufacturers. DC marked it as another experience:

"I did not care that much about if we didn't do it. It was fun but I did not feel that connected to it. [...] On the one handhand, I wanted to create my own company so I guess the drive is also to do something. I know I was a little bit stressed when the company lacked experience, because I know I wanted to do something".

For DC, the motivation came with the third venture, started as part of the program at Chalmers School of Entrepreneurship at 27 years old. The structure around the programme differentiated the experience from the previous ones: 
"the The school was a network, of course. The app developers are from the IT department here at Chalmers. So we came in contact with them basically because we are Chalmers also. This device was very critical because none of us have the IT competence. Now we are almost launching so we have built up without any skills internally. [...] Just to have an office. [...] I think almost the most important thing, we go there every day and we sit in our same placesday, we sit in our same places, and we do the routines. It feels like work. "

DC and his teammates are continuing with their venture, having secured a number of pilot customers in Gothenburg, with aims to expand into Europe. The team has been a critical source of motivation, but it has also been valuable to learn the process of how to develop a more technology-based venture:

" $a \underline{A}$ 'right way' process of doing things because both [of the previous companies] were more [about] doing something. We just did actually something without knowing how to do it. [Now we] follow, like, how we should do things, like the cold calling, and the lean start-up, and effectuation, like what we have in the team and what we can do with ourselves, and what we have studied now".

\section{C-Chalmers (CC)}

CC's entrepreneurial interest started with a focus on creativity instead of a business intention. Growing up, CC worked developing clubs activities and events in his hometown. In high school, he took part in the Youth Business Association course (Ungföretagsamhet), starting a small business with some classmates:

"we did the classic, by something, sell to the other one. We bought ties, from the 70s, made of leather, and they were produced in West Germany".

Besides having fun, the motivation was to see if the venture could win any of the awards associated with Ungföretagsamhet. CC and his partners evaluated the options relative to their personal strengths:

"meMe and K-External, we spent a lot of time on the presentation because we sort of took all these categories or these fields for competition and we looked at said, okay, within which competition is it possible for us to win? ... The product wasn't that good. But we made a great presentation." 
Ultimately though, it came back to CC's creativity drive: "you are required to do some sort of project work to finish off [but, for me] there was some sort of force just dragging me towards it. I don't know if it was the curiosity part of me or if it was, ... was ... about creating something."

At university, CC continued his emphasis on engagement with entrepreneurial activity, driven by a need to create and build something, manifested in various forms. Together with classmates from Chalmers, CC started a student association for entrepreneurs:

"[J-External] came to me and said, hey, how about starting an association for entrepreneurship. I think that is needed because entrepreneurship is centralized at Chalmers at the School of Entrepreneurship, and there are plenty of students that have this need for entreprenourial mindedentrepreneurial-minded [stuff]. And I said, well, you should talk to JSExternal who was working with this question from the Student Union board. So they connected, they talked, and then J-External pulled me in".

At the same time, he also started a business accelerator for the development of student ideas: "what we ended up with, starting to build, was (...) the business accelerator for students". All of these endeavours stem from CC's creativity interest, but also from wanting to create value for others because "for me it was again creating something. Building something and sort of transfer the feeling of connecting people. Because that is also something that I enjoy doing".

CC continues his studies at Chalmers, but is also now working for a company, "taking part in building up a new business area, or a new company, within the company group, where I have the responsibility for sales".

\section{S-Chalmers (SC)}

SC grew up in an entrepreneurial family; both SC's father and uncle run their own companies and have always encouraged SC in her entrepreneurial interests. The decision between staying in northern Sweden or going to Chalmers was essential to where SC is today. Indeed, she wanted a technical education:

"my My best friend at the time and I applied for Chalmers, and then my choice of education was, okay - let's go away, because I don't have a clue of what I am going to do. I have an interest in finance and business but I also have an interest in natural sciences and technology, so industrial engineering. I thought it would be something that would fit me well'. 
During her bachelor studies, she engaged with different student groups regarding entrepreneurship; and just the common perspective steered her away from a more traditional career track. SC did her masters studies at the Chalmers School of Entrepreneurship, during which, in the $2^{\text {nd }}$ year she was part of a team developing "a cleantech start-up. We develop a solution to use energy from ocean waves". The team experienced a lot of team conflict during this period:

" $a$ A lot of the activities or a lot of my energy was focused on getting a team together and understanding each other and understanding the team dynamics. Which was rather the focus than actually developing the idea. And that has had an impact in many ways. (...) learned a lot of things about knowing what not to do, how not to act. The importance of having a team, and a team that is really complementary in terms of (...) personality. In terms of values".

Knowledge which was important to the development of the companyKnowledge that was important to the development of the company included industry information, and specifically detail about the renewable energy industry, and SC's background of integrating business with technology was important to this. But However, something particularly gained through the school was applying entrepreneurial tools often seen as more common to IT development:

"[my My company] is a super long-term - we are not developing an app (...) iltt's resource heavy. But what l've learned is that you can use the same tools, (...) the same thinking, or packaging, as when you develop an IT-based idea. And you can apply that to type of ideas or businesses [like my company]. (...) I don't think other developers in our industry apply that type of mind or toolset".

SC also stresses the importance of her cohort of classmates, "it helped a lot to have like-minded people around you in the same situation", and in particular those that also continued with their ventures after graduating, "I was alone [in the company], but I was not alone in being alone". This was which what changed their relationship from peers to close friendship.

A critical connection for the company and SC was meeting A-External, the current technical director in the company. SC met AE through the process of building the first scale prototype, having attracted funding for this during the incubation period, though $A E$ comes from another university in Sweden. Other important stakeholders were also developed either during the incubation time, or as part of the school network. 


\section{Discussion}

From a general perspective, the 'educational triad' of formal, non-formal and informal educational programmes-learning related to entrepreneurship (Coombs et al $\mathrm{l}_{2}$ 1973), has been described briefly in two universities as exemplars. Similar to previous studies (Ibrahim and Soufani, 2002; Karlan and Valdivia, 2011; Klofsten, 2000), the use of non-formal educational programmes was observed. With the unique educational objective of developing entrepreneurial competences, the analysed contexts considers entrepreneurship programmes that require formal, non-formal and informal activities to deliver the desired learning outcomes (Edwards and Muir, 2005; Honig, 2004). Moreover, through the analysis and comparison of the entrepreneurial activities, as critical incidents, of entrepreneurs situated within the two university settingscoming from the two studied settings, the perception and attitudes about their perceived learning se programmes-were described and analysed.

In general, the relevance of networks is clear and the entrepreneur's network awareness increased through their entrepreneurial journey from "don't know" to "know" to "need". For example, one of the entrepreneurs stated how he enrolled in a mastersmaster's degree to gain more practical knowledge about enterprise $a_{2} d_{2}$ in particular, to meet other like-minded people. This is in line with previous literature analysing how some entrepreneurship education programmes connect students to the 'real world', to entrepreneurs (Gordon et al, 2012; Lans et al, 2011). What the findings show is the relevance of social context for these entrepreneurs and how their links to this context enabled them to draw on it for entrepreneurship. This social context was clearly invoked for entrepreneurship through network ties. This context and the resources which lay within it, added value to the activity the entrepreneurs were engaged in and allowed them to access valuable contacts such as, for example, other entrepreneurs, mentors, potential clients/suppliers but also acquire resources, adding to the learning experience.

Regarding the two universities, it was surprising to see that Leeds entrepreneurs started to engage in entrepreneurial activities as teenagers, whereas two of the three Chalmers entrepreneurs started in their early twenties-adult years. However, all entrepreneurs tended to use an informal network as well as informal learning to carry outn their first entrepreneurial activity, regardless of when they started or where they came from. 
Addressing the first research question - how does entrepreneurial learning develop before, during and after students' involvement in universities? It seems that interviewed entrepreneursfespondents entrepreneurial learning follows a pattern. Early stages of the entrepreneurial journey relied on informal learning (TED-talks, conversations with relatives or friends, online resources); but as interviewed entrepreneurs respondents' entrepreneurial activities involve a more complex structure and a wider network of clients, they become aware of their need for more formal learning. To satisfy this need, interviewed entrepreneurs respondents engaged in non-formal learningeducation programmes (boot_camps, workshops and seminars) and, when necessary, they enrolled in formal education programmes courses (degrees or masters). Nevertheless, interviewed entrepreneurs respondents-also more often used informal learning other sources-to cover their knowledge gaps.; most often relying on informal learning means to fill these gaps. Consequently, this shows how there are teachable and non-teachable entrepreneurship elements (Rae and Carswell, 2001; Shepherd and Douglas, 1997), which are acquired through different activities, and how interdisciplinarity and

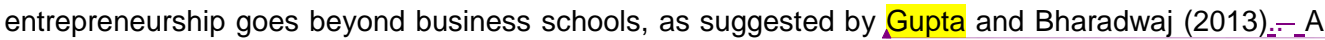
further interesting feature was that interviewed entrepreneurs espondents-sought other people with whom they could become associated with to associate-or hire in order to address their knowledge or skills gaps; this increased their awareness about the need for a network that could help them develop their business when they were not able to do it through acquired learning. This contributes to the call for more research about the relationship between entrepreneurship education at universities and entrepreneurial behaviourcompetence (Matlay, 2008). In fact, it was this awareness which seemed to transform the role of entrepreneurial learning after university into the pursuit of social capital: it was no longer about learning new areas of business (accountancy, marketing, and programming) but finding the right person who could be part of their team. However, how universities should respond to this need, as suggested by Man (2007) and Werkins (2010), remains under-explored.

The second research question was - how does entrepreneurial social networking develop before, Formatted: Highlight Formatted: Highlight during and after students' involvement in universities? Dealing with this question highlights the importance of entrepreneurs' relations with a network and its added value. Even though social networking is mostly based on informal networks during the early stages of the interviewed entrepreneursrespondents' entrepreneurial activity, informal networks are always present on their entrepreneurial journey. Actually, before university, the support of the family and friends support-was 
essential for interviewed entrepreneurs espondents-to develop their business, whether to help them to know potential customers or to organise the business. Buthowever, once they became engaged

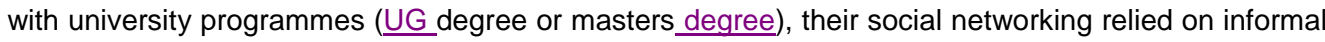
as well as formal networks. Classmates, guest speakers and academic mentors became part of their networks and provided them with both the confidence to be entrepreneurial and the resources needed to do it. And it is in this sense that we use the term entrepreneurial social networking as the activitiy and the network that provide added value to the interviewed entrepreneur by allowing him/her accessing valuable contacts (other entrepreneurs, mentors, potential clients/suppliers). Consequently, we add to discussions about how entrepreneurship education programmes provide an initial network (Gordon et al-, 2012; Lans et al-, 2011). Interestingly, when they gained entrepreneurship experience interviewed entrepreneurs respondents-realised that a wider network was central to their social capital. This awareness is what makes them look for specific contacts to develop their network in order to pursue their future career plans/-goals. Sometimes, this need for social capital led them to abandon their role of entrepreneur to become an intrapreneur within a company, which, in principle, goes against previous results stating that the propensity to be an entrepreneur is increased when s/he gains access to social capital (Bauernschuster et al., 2010; Westlund et al, 2014).

Finally, regarding the third research question - is it possible to establish a relationship between students' entrepreneurial social networking and entrepreneurial learning in universities? Results suggest that the intertwining of social networking and learning in entrepreneurship occurs before university, at the very first moment individuals engage in some type of entrepreneurial activity, and involving connections and interactions that take place between individuals (Anderson et al., 2007). As mentioned, the university provides the students with access to the 'real world' (Gordon et al, 2012; Lans et al, 2011) and opportunities for to-social networking relied on informal as well as formal networks (classmates, guest speakers and academic mentors) who may become relevant, as entrepreneurial networks, who add value to the nascent entrepreneurs (Foxton and Jones, 2011), as individuals who support, advice or even finance the entrepreneur's growth (Bosma et al, 2004; Casson and Della Giusta, 2007; Kim and Aldrich, 2005). 


\section{Conclusion}

This article has explored the relationship between the role of social networking and entrepreneurial learning by investigating the entrepreneurial journey of student and graduate entrepreneurs in two relevant and well-known European universities. It has described how entrepreneurship education programmes in these universities have been using various means to connect students to the 'real world', providing students with an initial network of entrepreneurs and the skills to develop their own network. In addition, the real impact of networking on student learning has been explored and some implications have been extracted from this. The metaphor of 'Lost in Space' has been used to illustrate the diffuse learning opportunities available within the university context, not yet fully obvious for either the student, or the educator. The lived experience of students/graduates engaging in an entrepreneurial journey while at university has illustrated the important contribution of social networking to entrepreneurial learning.

In conclusion, the intertwining of social networking and learning in entrepreneurship occurs before university, when the individuals engage in some type of entrepreneurial activity. University provides students with a needed maturity to realise that this intertwining is more complex than expected and that universities can provide them with formal and non-formal education, but also with the network of academics, classmates and entrepreneurs (that act as guest speakers and advisors) they develop during their studies, which allow them to gain informal learning, becominges an essential part of their entrepreneurial social capital.

Consequently, the contribution of this article is to expose the previously missing value of social networking in entrepreneurship education in universities and how this links to the acquisition of social capital. As implications, institutionally, it legitimates universities to include social networking activities into formal and non-formal entrepreneurship education. Moreover, at an individual level, it motivates educators to embed these activities within the curriculum that facilitate students' informal learning.

Regarding the limitations of the article, firstly, although it is possible through this pilot study to establish a relationship between students' entrepreneurial social capital and entrepreneurial learning in universities, it does not allow us to fully understand this relationship and the interconnectedness between formal, non-formal and informal elements of the proposed 'Bermuda TriangleLost in Space' 
in entreprenourship education. More research is needed to understand the entrepreneur's journey by considering not only entrepreneurial activities as critical incidents but other moments of the entrepreneur's life that help them to become entrepreneurs and not only the relations with agents coming from the university, but from outside (e.g. extended family, friends).- Secondly, the sample is small and considers only two universities in two different countries. Using a bigger number of entrepreneurs coming from different contexts would help to generalize the results of the study.

\section{References}

Aldrich, H., and Zimmer, C. (1986), 'Entrepreneurship through social networks. The art and science of entrepreneurship', in Sexton, D.L., and Smilor, R.W., eds, The Art and Science of Entrepreneurship, Ballinger Publishing, Cambridge, MA, pp 3-23.

Anderson, A. R., and Jack, S. (2002), 'The articulation of social capital in entrepreneurial networks: A glue or a lubricant?' Entrepreneurship and Regional Development, Vol 14 No 3, pp 193-210.

Anderson, A., Park, J., and Jack, S. (2007), 'Entrepreneurial Social Capital Conceptualizing Social Capital in New High-tech Firms', International Small Business Journal, Vol 25, No 3, pp 245-272.

Armitage, W.D., Jones, W.D., Langsam, S., Manullang, D., and Plank, R.E. (2011). A Soft Landing Case Study: Integrating Students and Faculty into Incubator Operations, International Journal of Polytechnic Studies, Vol 1 No 1, pp 1-12.

Bauernschuster, S., Falck, O., and Heblich, S. (2010), 'Social capital access and entrepreneurship', Journal of Economic Behavior \& Organization, Vol 76, No 3, pp 821-833.

Béchard, J.P., and Toulouse, J.M. (1998), 'Validation of a didactic model for the analysis of training objectives in entrepreneurship', Journal of Business Venturing, Vol 13, No 4, pp 317-332.

Birley, S. (1985), 'The Role of Networks in the Entrepreneurial Process', Journal of Business Venturing, Vol 1 No 1, pp 107-117.

Blackwood, T., Round, A., Pugalis, L., and Hatt, L. (2015), 'Making sense of learning: Insights from an experientially-based undergraduate entrepreneurship programme', Industry and Higher Education, Vol 29 No 6, pp 445-457.

Bosma, N., Van Praag, M., Thurik, R., and De Wit, G. (2004), 'The value of human and social capital investments for the business performance of startups', Small Business Economics, Vol 23 No 3, pp 227-236. 
Byrne, J., Fayolle, A., and Toutain, O. (2014). Entrepreneurship Education: What We Know and What We Need to Know, in Chell, E., and Karatas-özkan, M., eds., Handbook of Research in Entrepreneurship and Small Business, Cheltenham, UK, Edward Elgar, pp 261-288.

Cassell, C., and Symon, G., eds, (2004), Essential guide to qualitative methods in organizational research. Sage, London.

Casson, M., and Della Giusta, M. (2007), 'Entrepreneurship and social capital. Analysing the impact of social networks on entrepreneurial activity from a rational action perspective', International Small Business Journal, Vol 25 No 3, pp 220-244.

Cedefop (2011), 'Guidance Supporting Europe's Aspiring Entrepreneurs. Policy and practice to harness future potential'. Research Paper, No 14, Publications Office of the European Union, Luxembourg, [Available online] http://www.cedefop.europa.eu/EN/Files/5514 en.pdf (accessed 19 July 2016)

Chen, M.H., Chang, Y.Y., and Chang, Y.C. (2015), 'Entrepreneurial Orientation, Social Networks, and Creative Performance: Middle Managers as Corporate Entrepreneurs', Creativity and Innovation Management, Vol 24, No 3, pp 493-507.

Coombs, P.H., Prosser, R.C., and Ahmed, M. (1973), New Paths lo Learning for Rural Children and Youth, International Council for Educational Development (ICED), New York.

Cope, J., Jack, S., and Rose, M.B. (2007), 'Social Capital and Entrepreneurship An Introduction', International Small Business Journal, Vol 25 No 3, pp 213-219.

Creswell, J.W. (2013), Research design: Qualitative, quantitative, and mixed methods approaches, Sage, California.

Cruz, N., Escudero, A., Barahone, J., and Leitao, F. (2009), 'The effect of entrepreneurship education programmes on satisfaction with innovation behavior and performance', Journal of European Industrial Training, Vol 33 No 3, pp 198-214.

Dawson, C., Fuller-Love, N., Sinnott, E., and O'Gorman, B. (2011), 'Entrepreneurs' perceptions of business networks: does gender matter?', International Journal of Entrepreneurship and Innovation, Vol 12 No 4, pp 271-281.

Deakins, D., and Freel, M. (1998), 'Entrepreneurial learning and the growth process in SMEs', The Learning Organization, Vol 5 No 3, pp 144-155.
Formatted: Font: (Default) Arial, 10 pt, English (U.K.), Check spelling and grammar, Highlight

Formatted: Indent: Left: $0 \mathrm{~cm}$, Hanging: $0.5 \mathrm{~cm}$, Line spacing: Double

Formatted: English (U.K.), Check spelling and grammar

Formatted: Font: (Default) Arial, 10 pt, English (U.K.), Check spelling and grammar

Formatted: Highlight

Formatted: Highlight

Formatted: Highlight

\section{Formatted: Highlight}

Formatted: Highlight

Formatted: Highlight

Formatted: Highlight

Formatted: Highlight

Formatted: Highlight

Formatted: Highlight 
Eagle, N., Macy, M., and Claxton, R. (2010), 'Network diversity and economic development', Science, Vol 328 No 5981, pp 1029-1031.

Edwards, L.J., and Muir, E.J. (2005), 'Promoting entrepreneurship at the University of Glamorgan through formal and informal learning', Journal of Small Business and Enterprise Development, Vol 12 No 4, pp 613-626.

Estrin, S., Mickiewicz, T., and Stephan, U. (2013), 'Entrepreneurship, social capital, and institutions: Social and commercial entrepreneurship across nations', Entrepreneurship Theory and Practice, Vol 37 No 3, pp 479-504.

European Commission (2012), Effects and impact of entrepreneurship programmes in higher education [Available online]

http://ec.europa.eu/DocsRoom/documents/375/attachments/1/translations/en/renditions/native (accessed 19 July 2016)

European Commission (2014), Tackling Early Leaving from Education and Training in Europe: Strategies, Policies and Measures, Publications Office of the European Union, Luxembourg.

European Commission (2015), The European Higher Education Area in 2015: Bologna Process Implementation Report, Publications Office of the European Union, Luxembourg.

Fayolle, A., Gailly, B., and Lassas-Clerc, N. (2006), 'Assessing the impact of entrepreneurship education programmes: a new methodology', Journal of European Industrial Training, Vol 30 No 9, pp 701-720.

Formica, P. (2002), 'Entrepreneurial universities: the value of education in encouraging entrepreneurship', Industry and Higher Education, Vol 16 No 3, pp 167-175.

Foxton, F., and Jones, R. (2011), Social capital indicators review, Office for National Statistics, UK.

Gephart, R.P. (2004), 'Qualitative research and the Academy of Management Journal', Academy of Management Journal, Vol 47 No 4, pp 454-462.

Gibb, A. (2005). Towards the entrepreneurial university. Entrepreneurship education as a level for change. UK: National Council for Graduate Entrepreneurship. [Available online] http://ncee.org.uk/wp-content/uploads/2014/06/towards the entrepreneurial university.pdf (accessed 19 July 2016)

Gibb, A., Haskins, G., and Robertson, I. (2013), 'Leading the entrepreneurial university: Meeting the entrepreneurial development needs of higher education institutions', In Altmann, A. and
Formatted: Highlight

Formatted: Highlight

Formatted: Highlight

Formatted: Highlight

\section{Formatted: Highlight}

Formatted: Highlight

Formatted: Highlight

Formatted: Highlight

Formatted: Highlight

Formatted: Highlight

Formatted: Highlight

Formatted: Highlight 
Ebersberger, B., eds., Universities in Change, Innovation, Technology, and Knowledge Management, Springer Science+Business Media, New York, pp 9-45.

Gordon, I., Hamilton, E., and Jack, S. (2012), 'A study of a university-led entrepreneurship education programme for small business owner/managers', Entrepreneurship \& Regional Development, Vol 24 No 9-10, pp 767-805.

Granovetter, M. (1985), 'Economic action and social structure: the problem of embeddedness', American Journal of Sociology, Vol 91 No 3, pp 481-510.

Greene, F.J., and Saridakis, G. (2007), Understanding the factors influencing graduate entrepreneurship, National Council for Graduate Entrepreneurship Research Report, 1/2007, NCGE, Birmingham.

Gupta, N., and Bharadwaj, S. (2013), 'Agility in business school education through richness and reach: a conceptual model', Education+ Training, Vol 55 No 4/5, pp 370-384.

Henry, C., Hill, F., and Leitch, C. (2005), 'Entrepreneurship education and training: can entrepreneurship be taught? Part l', Education+ Training, Vol 47 No 2, pp 98-111.

Higgins, D. and Elliott, C. (2011), 'Learning to make sense: What works in Entrepreneurial Education?' Journal of European Industrial Training, Vol 35 No 4, pp 345-367.

Higgins, D., and Galloway, L. (2014), 'Refocusing-building a future for entrepreneurial education and learning', Industry and Higher Education, Vol 28 No 6, pp 449-457.

Hill, S.E. (2011), The impact of entrepreneurship education. An exploratory study of MBA graduates in Ireland. MSc dissertation. University of Limerick. [Available online] http://ulir.ul.ie/bitstream/handle/10344/1663/2011 Hill\%2c\%20Shane.pdf?sequence=5 (accessed 19 July 2016)

Honig, B. (2004), 'Entrepreneurship education: Toward a model of contingency-based business planning', Academy of Management Learning \& Education, Vol 3 No 3, pp 258-273.

$\underline{\text { Ibrahim, A.B., and Soufani, K. (2002), 'Entrepreneurship education and training in Canada: a critical }}$ assessment', Education + Training, Vol 44 No 8/9, pp 421-430.

Jack, S. (2005), 'The role, use and activation of strong and weak ties: A qualitative analysis', Journal of Management Studies, Vol 42 No 6, pp 1233-59.

Jack, S. (2010), 'Approaches to studying networks: implications and outcomes', Journal of Business Venturing, Vol 25 No 1, pp 120-137. 
Jack, S., Moult, S., Anderson, A.R., and Dodd, S. (2010), 'An entrepreneurial network evolving: Patterns of change', International Small Business Journal, Vol 28 No 4, pp 315-337.

Janssen, F., Eeckhout, V., and Gailly, B. (2007), 'Interdisciplinary approaches in entrepreneurship education programs', in Fayolle, A., ed, Handbook of research in entrepreneurship education, vol. 2. Edward Elgar Publishing Limited, Glos, UK, pp 148-165.

Johannisson, B. (2016). Limits to and prospects of entrepreneurship education in the academic context. Entrepreneurship \& Regional Development, 1-21.

Karlan, D., and Valdivia, M. (2011), 'Teaching entrepreneurship: Impact of business training on microfinance clients and institutions', Review of Economics and Statistics, Vol 93 No 2, pp 510$\underline{527 .}$

Kim, P., and Aldrich, H. (2005), Social capital and entrepreneurship, Now Publishers Inc.. Hanover, MA.

Klofsten, M. (2000), 'Training entrepreneurship at universities: a Swedish case', Journal of European Industrial Training, Vol 24 No 6, pp 337-344.

Knapper, C., and Cropley, A.J. (2000), Lifelong learning in higher education, Psychology Press, London.

Lackéus, M., and Williams Middleton, K. (2015), 'Venture Creation Programs: bridging entrepreneurship education and technology transfer', Education + Training, Vol 57 No 1, 48-73.

Lackéus, M., and Williams Middleton, K. (2015), Venture Creation Programs: bridging entrepreneurship education and technology transfer, Education + Training, Vol, 57 No 1, pp 48-73.

Lans, T., Verstegen, J., and Mulder, M. (2011), 'Analysing, pursuing and networking: Towards a validated three-factor framework for entrepreneurial competence from a small firm perspective', International Small Business Journal, Vol 29 No 6, pp 695-713.

Light, I., and Dana, L.P. (2013), 'Boundaries of social capital in entrepreneurship', Entrepreneurship Theory and Practice, Vol 37 No 3, pp 603-624.

Lundqvist, M. and Williams Middleton, K. (2008), 'Sustainable Wealth Creation beyond Shareholder Value', in Wanker, C., and Stoner, J., eds, Innovative Approaches to Global Sustainability, Palgrave MacMillan, New York, NY.

Lundqvist, M.A. (2014), The importance of surrogate entrepreneurship for incubated Swedish technology ventures, Technovation, Vol 34 No 2, pp 93-100.
Formatted: Highlight

Formatted: Highlight

Formatted: Font: (Default) Arial, 10 pt, English (U.K.), Check spelling and

grammar, Highlight

Formatted: Indent: Left: $0 \mathrm{~cm}$

Hanging: $0.5 \mathrm{~cm}$, Line spacing: Double

Formatted: Highlight

Formatted: Highlight

Formatted: Highlight

Formatted: Highlight

Formatted: Highlight

Formatted: Highlight

Formatted: Font: (Default) Arial, 10

pt, English (U.K.), Check spelling and grammar, Highlight

Formatted: Indent: Left: $0 \mathrm{~cm}$ Hanging: $0.5 \mathrm{~cm}$, Line spacing: Double

Formatted: Font: Not Italic, English (U.K.), Check spelling and grammar

Formatted: English (U.K.), Check

spelling and grammar

Formatted: Font: (Default) Arial, 10 pt, Not Italic, English (U.K.), Check spelling and grammar

Formatted: Highlight

Formatted: Highlight

Formatted: Highlight

Formatted: English (U.K.), Check spelling and grammar, Highlight

Formatted: Indent: Left: $0 \mathrm{~cm}$ Hanging: $0.5 \mathrm{~cm}$, Line spacing: Double

Formatted: English (U.K.), Check spelling and grammar

Formatted: Font: (Default) Arial, 10 pt, English (U.K.), Check spelling and grammar 
Man, T.W.Y. (2007), 'Understanding entrepreneurial learning. A competency approach', International Journal of Entrepreneurship and Innovation, Vol 8 No 3, pp 189-198.

Matlay, H. (2008), 'The impact of entrepreneurship education on entrepreneurial outcomes', Journal of Small Business and Enterprise Development, Vol 15 No 2, pp 382-396.

Matlay, H., and Carey, C. (2007), 'Entrepreneurship education in the UK: a longitudinal perspective', Journal of Small Business and Enterprise Development, Vol 14 No 2, pp 252-263.

McKeever, E., Jack, S., and Anderson, A. (2015), 'Embedded entrepreneurship in the creative reconstruction of place', Journal of Business Venturing, Vol 30 No 1, pp 50-65.

McQueen, D.H. and Wallmark, J.T. (1982), 'Spin-off Companies from Chalmers University of Technology', Technovation, Vol 1, No 4, pp 305-315.

McQueen, D.H. and Wallmark, J.T. (1984), 'Innovation Output and Academic Performance at Chalmers University of Technology', Omega, Vol 12 No 5, pp 457-464.

Meyer, A.D., Aten, K., Krause, A.J., Metzger, M.L., and Holloway, S.S. (2011), Creating a university^ technology commercialisation programme: confronting conflicts between learning, discovery and commercialisation goals, International Journal of Entrepreneurship and Innovation Management, Vol 13 No 2, pp 179-198.

Naia, A., Baptista, R., Januário, C., and Trigo, V. (2014), 'A systematization of the literature on entrepreneurship education: challenges and emerging solutions in the entrepreneurial classroom', Industry and Higher Education, Vol 28 No 2, pp 79-96.

Neck, H., and Greene, P. (2011), Entrepreneurship Education: Known Worlds and New Frontiers, 4 Journal of Small Business Management, Vol 49 No 1, pp 55-70.

Neergaard, H., and Ulhoi, J.P., eds, (2007), Handbook of qualitative research methods in entrepreneurship, Edward Elgar Publishing, Glos, UK.

Ngaka, W., Openjuru, G., and Mazur, R.E. (2012), 'Exploring Formal and Non-formal Education Practices for Integrated and Diverse Learning Environments in Uganda', International Journal of Diversity in Organizations, Communities and Nations, Vol 11 No 6, 109-121.

OECD (2013), Entrepreneurship at a Glance. OECD Publishing. [Available online] http://dx.doi.org/10.1787/entrepreneur aag-2013-en (accessed 19 July 2016)
Formatted: Highlight

Formatted: Highlight

Formatted: Highlight

Formatted: Highlight

Formatted: Highlight

Formatted: Highlight

Formatted: English (U.K.), Check spelling and grammar, Highlight

Formatted: Indent: Left: $0 \mathrm{~cm}$, Hanging: $0.5 \mathrm{~cm}$, Line spacing: Double

Formatted: English (U.K.), Check

spelling and grammar

Formatted: Font: (Default) Arial, 10 pt, English (U.K.), Check spelling and grammar

Formatted: Highlight

Formatted: Font: (Default) Arial, 10 pt, English (U.K.), Check spelling and grammar, Highlight

Formatted: Indent: Left: $0 \mathrm{~cm}$ Hanging: $0.5 \mathrm{~cm}$, Line spacing: Double

Formatted: Highlight

Formatted: Highlight

Formatted: Highlight 
Piperopoulos, P. (2012), 'Could higher education programmes, culture and structure stifle the entrepreneurial intentions of students?', Journal of Small Business and Enterprise Development, Vol 19 No 3, pp 461-483.

Pittaway, L., and Cope, J. (2007), 'Entrepreneurship education a systematic review of the evidence', International Small Business Journal, Vol 25 No 5, pp 479-510.

Pittaway, L., Rodriguez-Falcon, E., Aiyegbayo, O., and King, A. (2011), 'The role of entrepreneurship clubs and societies in entrepreneurial learning', International Small Business Journal, Vol 29 No 1. pp 37-57.

Pittaway, L.A., Gazzard, J., Shore, A., and Williamson, T. (2015), Student clubs: experiences inentrepreneurial learning, Entrepreneurship \& Regional Development, Vol 27 No 3-4, pp 127-153.

Rae, D. (2010), 'Universities and enterprise education: responding to the challenges of the new era', Journal of Small Business and Enterprise Development, Vol 17 No 4, pp 591-606.

Rae, D., and Carswell, M. (2001), 'Towards a conceptual understanding of entrepreneurial learning', Journal of Small Business and Enterprise Development, Vol 8 No 2, pp 150-158.

Sarasvathy, S.D. and Dew, N. (2005), 'Entrepreneurial logics for a technology of foolishness', Scandinavian Journal of Management, Vol 21 No 4, pp 385-406.

Saunders, M.N.K., Gray, E.D., and Goregaokar, H. (2013), 'SME innovation and learning: the role of networks and crisis events', European Journal of Training and Development, Vol 38 No 1/2, pp $\underline{136-149}$

Sharma, P., and Choudhary, A. (2015), 'Learning in Different Educational Settings; Methodological Concerns', Journal of Humanities and Social Science, Vol 20 No 4, pp 18-25.

Shepherd, D.A., and Douglas, E.J. (1997), Is management education developing, or killing, the entrepreneurial spirit, in Proceedings of the 1997 USASBE Annual National Conference 'Entrepreneurship: The Engine of Global Economic Development', San Francisco, California.

Sirelkhatim, F., and Gangi, Y. (2015), Entrepreneurship education: A systematic literature review of curricula contents and teaching methods, Cogent Business \& Management, Vol 2 No 1, 1052034.

Skule, S. (2004), 'Learning conditions at work: a framework to understand and assess informal learning in the workplace', International Journal of Training and Development, Vol 8 No 1, pp 8-20.
Formatted: Highlight

Formatted: Highlight

Formatted: Highlight

Formatted: English (U.K.), Check spelling and grammar, Highlight

Formatted: Indent: Left: $0 \mathrm{~cm}$, Hanging: $0.5 \mathrm{~cm}$, Line spacing:

Double

Formatted: English (U.K.), Check spelling and grammar

Formatted: Font: (Default) Arial, 10 pt, English (U.K.), Check spelling and grammar

Formatted: English (U.K.), Check spelling and grammar

Formatted: Highlight

Formatted: Highlight

Formatted: Highlight

Formatted: Highlight

Formatted: Highlight

Formatted: Highlight

Formatted: Font: (Default) Arial, 10 pt, English (U.K.), Check spelling and grammar, Highlight

Formatted: Indent: Left: $0 \mathrm{~cm}$

Hanging: $0.5 \mathrm{~cm}$, Line spacing:

Double

Formatted: Highlight 
Slattery, G., and Danaher, M. (2015), Curriculum design: A gestalt approach to the pedagogy of entrepreneurship education with postgraduate student teachers in an Irish university, Journal for Educators, Teachers and Trainers, 6.

Smith, K. (2015), 'Measuring the impact of enterprise education and entrepreneurship support in higher education: Can routinely collected data be of use?', Industry and Higher Education, Vol 29 No 6, pp 493-503.

Souitaris, V., Zerbinati, S., Al-Laham, A. (2007), 'Do entrepreneurship programmes raise entrepreneurial intention of science and engineering students? The effect of learning, inspiration and resources', Journal of Business Venturing, Vol 22 No 4, pp 566-591.

Stam, W., and Elfring, T. (2008), 'Entrepreneurial orientation and new venture performance: The moderating role of intra-and extraindustry social capital', Academy of Management Journal, Vol 51 No 1, pp 97-111.

Stam, W., Arzlanian, S., and Elfring, T. (2014), 'Social capital of entrepreneurs and small firm performance: A meta-analysis of contextual and methodological moderators', Journal of Business Venturing, Vol 29 No 1, pp 152-173.

University of Leeds (2015), Enterprise Impact Report 2014-15. University of Leeds. [Available online] https://www.leeds.ac.uk/downloads/download/90/enterprise impact report 2014-15 (accessed 19 July 2016)

von Graevenitz, G., Harhoff, D., and Weber, R. (2010), 'The effects of entrepreneurship education', Journal of Economic Behavior \& Organization, Vol 76 No 1, pp 90-112.

Werkins, P. (2010), Recognition of non-formal and informal learning: country practices. [Available online] http://www.connect.tsoft.hu/digitalcity/servlet/PublishedFileServlet/AAABEWBX/OECDReport.pdf (accessed 19 July 2016)

Westlund, H., and Adam, F. (2010), 'Social capital and economic performance: A meta-analysis of 65 studies', European Planning Studies, Vol 18 No 6, pp 893-919.

Westlund, H., Larsson, J.P., and Olsson, A.R. (2014), 'Start-ups and local entrepreneurial social capital in the municipalities of Sweden', Regional Studies, Vol 48 No 6, pp 974-994.

Williams Middleton, K., and Donnellon, A. (2014), Personalizing Entrepreneurial Learning: A Pedagogy for Facilitating the Know Why, Entrepreneurship Research Journal, Vol 4 No 2, 167$\underline{204 .}$
Formatted: Font: (Default) Arial, 10 pt, English (U.K.), Check spelling and grammar, Highlight

Formatted: Indent: Left: $0 \mathrm{~cm}$, Hanging: $0.5 \mathrm{~cm}$, Line spacing: Double

Formatted: Highlight

Formatted: Highlight

Formatted: Highlight

\section{Formatted: Highlight}

Formatted: Highlight

Formatted: Highlight

Formatted: Highlight

Formatted: Highlight

Formatted: Highlight

Formatted: Font: (Default) Arial, 10 pt, English (U.K.), Highlight

Formatted: Font: (Default) Arial, 10 pt, English (U.K.)

Formatted: Font: (Default) Arial, 10 pt, Not Italic, English (U.K.) 
Young, L. (2014), Enterprise for All. The relevance of enterprise in education. Department for Business, Innovation \& Skills and Prime Minister's Office. UK. [Available online] https://www.gov.uk/government/uploads/system/uploads/attachment data/file/338749/Enterprisefo rAll-lowres-200614.pdf (accessed 19 July 2016)

Aldrich, H., and Zimmer, C. (1986), 'Entrepreneurship through social networks. The art and science of entrepreneurship', in Sexton, D.L. Smilor, R.W., ods, The Art and Science of Entrepreneurship, Ballinger Publishing, Cambridge, MA, pp 3-23.

Anderson, A., Park, J., and Jack, S. (2007), 'Entrepreneurial Social Capital Conceptualizing Social Gapital in New High-tech Firms', International Small Business Journal, Vol 25, No 3, pp 245-272.

Bauernschuster, S., Falck, O., and Heblich, S. (2010), 'Social capital access and entreprenourship', Journal of Economic Behavior \& Organization, Vol 76, No 3, pp $821-833$.

Béchard, J.P., and Toulouse, J.M. (1998), 'Validation of a didactic model for the analysis of training objectives in entrepreneurship', Journal of Business Venturing, Vol 13, No 4, pp 317-332.

Blackwood, T., Round, A., Pugalis, L., and Hatt, L. (2015), 'Making sense of learning: Insights from an experientially-based undergraduate ontrepreneurship programme', Industry and Higher Education, Vol 29 No 6, pp-445-457.

Bosma, N., Van Praag, M., Thurik, R., and De Wit, G. (2004), 'The value of human and social capital investments for the business performance of startups', Small Business Economics, Vol 23 No 3, pp 227-236.

Gassell, G., and Symon, G., eds, (2004), Essential guide to qualitative methods in organizational research. Sage, London.

Casson, M., and Della Giusta, M. (2007), 'Entrepreneurship and social capital. Analysing the impact of social networks on entrepreneurial activity from a rational action perspective', International Small Business Journal, Vol 25 No 3, pp 220-244.

Cedefop (2011), 'Guidance Supporting Europe's Aspiring Entrepreneurs. Policy and practice to harness future potential'. Research Paper, No 14, Publications Office of the European Union, Luxembourg, [Available online] http://www.cedefop.europa.eu/EN/Files/5514_en.pdf-(accessed 19 duly 2016)
Formatted: Highlight

Formatted: English (U.K.)

Formatted: Highlight

Formatted: Highlight

Formatted: Highlight

Formatted: Highlight

Formatted: Highlight

Formatted: Highlight

Formatted: Highlight

Formatted: Highlight

Formatted: Highlight 
Chen, M.H., Chang, Y.Y., and Chang, Y.C. (2015), 'Entrepreneurial Orientation, Social Networks, and Greative Performance: Middle Managers as Corporate Entrepreneurs', Greativity and Innovation Management, Vol 24, No 3, pp-493-507.

Coombs, P.H., Prosser, R.C., and Ahmed, M. (1973), New Paths to Learning for Rural Children and Youth, International Council for Educational Development (ICED), New York.

Cope, J., Jack, S., and Rose, M.B. (2007), 'Social Gapital and Entreprenourship An Introduction', International Small Business Journal, Vol 25 No 3, pp 213-219.

Creswell, J.W. (2013), Research design: Qualitative, quantitative, and mixed methods approaches, Sage, California.

Gruz, N., Escudero, A., Barahone, d., and Leitae, F. (2009), 'The effect of entrepreneurship-education programmes on satisfaction with innovation behavior and performance', Journal of European Industrial Training, Vol 33 No 3, pp 198-214.

Dawson, C., Fuller-Love, N., Sinnott, E., and O'Gorman, B. (2011), 'Entrepreneurs' perceptions of business networks: does gender matter?', International Journal of Entrepreneurship and Innovation, Vol $12 \mathrm{No}-4$, pp $271-281$

Deakins, D., and Freel, M. (1998), 'Entrepreneurial learning and the growth process in SMEs', The tearning Organization, Vol 5No 3 , pp 144-155.

Eagle, N., Macy, M., and Claxton, R. (2010), 'Network diversity and economic development', Science, Vol 328 No 5981, pp 1029-1031.

Edwards, L.J., and Muir, E.J. (2005), 'Promoting entreprenourship at the University of Glamorgan through formal and informal learning', Journal of Small Business and Enterprise Development, Vol 12 No 4 , pp 613-626.

Estrin, S., Mickiewicz, T., and Stephan, U. (2013), 'Entrepreneurship, social capital, and institutions: Social and commercial entroprenourship across nations', Entreprenourship Theory and Practice, Vol 37 No 3 , pp $479-504$.

European Commission (2012), Effects and impact of entrepreneurship programmes in higher education, [Available online] http://og.europa.ou/DossRoom/documents/375/attachments/1/translations/en/renditions/native (accessed 19 July 2016)
Formatted: Highlight

Formatted: Highlight

Formatted: Highlight

Formatted: Highlight

Formatted: Highlight

Formatted: Highlight

Formatted: Highlight

Formatted: Highlight

Formatted: Highlight

Formatted: Highlight

Formatted: Highlight 
Europoan Commission (2014), Tackling Early Loaving from Education and Training in Europo: Strategies, Policies and Measures, Publications Office of the European Union, Luxembourg.

European Commission (2015), The European Higher Education Area in 2015: Bologna Process Implementation Report, Publications Office of the European Union, Luxembourg.

Fayolle, A., Gailly, B., and Lassas-Clerc, N. (2006), 'Assessing the impact of entrepreneurship education programmes: a new methodology', Journal of European Industrial Training, Vol $30 \mathrm{No} 9$, pp 701720

Formica, P. (2002), 'Entrepreneurial universities: the value of education in encouraging entrepreneurship', Industry and Higher Education, Vol 16 No 3, pp 167-175.

Foxton, F., and Jones, R. (2011), Social capital indicators roviow, Office for National Statistics, UK.

George, M. (2013), Evaluation of the LEAD programme: a ten-month leadership development initiative for SME owner-managers. Lancaster University Management School. Lancaster. [Available online] http://www.lancaster.ac.uk/media/lancaster-university/contentassets/documents/lums/business/LEADEvaluation2013.pdf (accessed 19 July 2016)

Gephart, R.P. (2004), 'Qualitative research and the Academy of Management Journal', Academy of Management dournal, Vol 47 No 4 , pp $454-462$.

Gibb, A. (2005), Towards the entrepreneurial university. Entrepreneurship education as a level for change. UK: National Council for Graduate Entrepreneurship. [Available online] http://nceo.org.uk/wp-content/uploads/2014/06/towards_the_entrepreneurial_university.pdf (accessed 19 July 2016)

Gibb, A., Haskins, G., and Robertson, 1. (2013), 'Leading the entrepreneurial university: Meeting the entrepreneurial development needs of higher education institutions', In Altmann, A. and Ebersberger, B., eds., Universities in Change, Innovation, Technology, and Knowledge Management, Springer Science+Business Media, Now York, pp 9-45.

Goldman Sachs (2014), Empowering entrepreneurs, accelerating growth. Progress report on the Goldman Sachs 10,000 Small Businesses UK Programme, Goldman Sachs, UK.

Gordon, I., Hamilton, E., and Jack, S. (2012), 'A study of a university-led entrepreneurship education programme for small business owner/managers', Entroprenourship \& Regional Dovelopment, Vol 24 No $9-10$, pp $767-805$.
Formatted: Highlight

Formatted: Highlight

Formatted: Highlight

Formatted: Highlight

Formatted: Highlight

Formatted: Highlight

Formatted: Highlight

Formatted: Highlight

Formatted: Highlight

Formatted: Highlight

Formatted: Highlight 
Granovetter, M. (1985), 'Economic action and social structure: the problem of embeddedness', American dournal of Sociology, Vol 91 No 3, pp $481-510$.

Greene, F.J., and Saridakis, G. (2007), Understanding the factors influencing graduate entrepreneurship, National Council for Graduate Entrepreneurship Research Report, 1/2007, NGGE, Birmingham.

Gupta, N., and Bharadwaj, S. (2013), 'Agility in business school oducation through richness and reach: a conceptual model', Education, Training, Vol 55 No $4 / 5$, pp $370-384$.

Henry, C., Hill, F., and Leitch, C. (2005), 'Entrepreneurship education and training: can entrepreneurship be taught? Part I', Education+ Training, Vol 47 No 2, pp 98-111.

Higgins, D. and Elliott, C. (2011), 'Learning to make sense: What works in Entrepreneurial Education?' dournal of European Industrial Training, Vol 35 No-4, pp 345-367.

Higgins, D., and Galloway, L. (2014), 'Refocusing-building a future for entrepreneurial education and learning', Industry and Higher Education, Vol 28 No 6, pp 449-457.

Hill, S.E. (2011), The impact of entrepreneurship education. An exploratory study of MBA graduates in freland. MSc dissertation. University of Limerick. [Available online] http://ulir.ul.ie/bitstream/handle/10344/1663/2011_Hill\%2c\%20Shane.pdf?sequence=5 (accessed 19 July 2016)

Honig, B. (2004), 'Entrepreneurship education: Toward a model of contingency-based business planning', Academy of Management Learning \& Education, Vol 3 No 3, pp 258-273.

Hbrahim, A.B., and Soufani, K. (2002), 'Entroprenourship oducation and training in Canada: a critical assessment', Education, Training, Vol 44 No 8/9, pp-421-430.

Jack, S., Moult, S., Anderson, A.R., and Dodd, S. (2010), 'An entrepreneurial network evolving: Patterns of change', International Small Business Journal, Vol 28 No 4, pp 315-337.

Janssen, F., Eeckhout, V., and Gailly, B. (2007), 'Interdisciplinary approaches in entrepreneurship education programs', in Fayolle, A., ed, Handbook of research in entrepreneurship education, vol. Z. Edward Elgar Publishing Limited, Glos, UK, pp 148-165.

Karlan, D., and Valdivia, M. (2011), 'Teaching entrepreneurship: Impact of business training on microfinance clients and institutions', Review of Economics and Statistics, Vol 93 No 2, pp 510 527.
Formatted: Highlight

Formatted: Highlight

Formatted: Highlight

Formatted: Highlight

Formatted: Highlight

Formatted: Highlight

Formatted: Highlight

Formatted: Highlight

Formatted: Highlight

Formatted: Highlight

Formatted: Highlight

Formatted: Highlight 
Kim, P., and Aldrich, H. (2005), Social capital and entreprenourship, Now Publishers Inc. Hanover, AAA.

Klofsten, M. (2000), 'Training entrepreneurship at universities: a Swedish case', dournal of European Industrial Training, Vol 24 No 6, pp 337-344.

Knapper, C., and Cropley, A.J. (2000), Lifelong learning in higher education, Psychology Press, London.

Lackéus, M., and Williams Middleton, K. (2015), venture Creation Programs: bridging entrepreneurship education and technology transfer', Education + Training, Vol 57 No 1, 48-73.

Lans, T., Verstegen, J., and Mulder, M. (2011), 'Analysing, pursuing and networking: Towards a validated three-factor framework for entrepreneurial competence from a small firm perspective', International Small Business dournal, Vol 29 No 6, pp 695-713.

Light, I., and Dana, L.P. (2013), 'Boundaries of social capital in entrepreneurship', Entrepreneurship Theory and Practice, Vol 37 No 3, pp 603-624

Lundqvist, M. and Williams-Middleton, K. (2008), 'Sustainable Wealth Creation beyond Shareholder Value', in Wanker, C., and Stoner, J., ods, Innovative Approaches to Global Sustainability, Palgrave AacAlllan, New York, NY.

Man, T.W.Y. (2007), 'Understanding entrepreneurial learning. A competency approach', International Journal of Entrepreneurship and Innovation, Vol 8 No 3, pp 189-198.

Matlay, H. (2008), 'The impact of entreprenourship education on entrepreneurial outcomes', Journal of Small Business and Enterprise Development, Vol 15 No 2, pp 382-396.

Matlay, H., and Carey, C. (2007), 'Entrepreneurship education in the UK: a longitudinal perspective', Journal of Small Business and Enterprise Development, Vol 14 No 2, pp 252-263.

McKeever, E., Jack, S., and Anderson, A. (2015), 'Embedded entrepreneurship in the creative reconstruction of place', Journal of Business Venturing, Vol 30 No 1 , pp $50-65$

McQueen, D.H. and Wallmark, J.T. (1982), 'Spin-off Companies from Chalmers University of Technology', Technovation, Vol 1, No-4, pp 305-315

McQueen, D.H. and Wallmark, J.T. (1984), 'Innovation Output and Academic Performance at Chalmers University of Technology', Omega, Vol 12 No 5, pp 457-464.
Formatted: Highlight

Formatted: Highlight

Formatted: Highlight

Formatted: Highlight

Formatted: Highlight

Formatted: Highlight

Formatted: Highlight

Formatted: Highlight

Formatted: Highlight

Formatted: Highlight

Formatted: Highlight

Formatted: Highlight

Formatted: Highlight

Formatted: Highlight 
Naia, A., Baptista, R., Januário, G., and Trigo, V. (2014), 'A systematization of the literature on entrepreneurship education: challenges and emerging solutions in the entrepreneurial classroom' Industry and Higher Education, Vol 28 No 2, pp 79-96.

Neergaard, H., and Uhoi, J.P., eds, (2007), Handbook of qualitative research methods in entrepreneurship, Edward Elgar Publishing, Glos, UK.

Ngaka, W., Openjuru, G., and Mazur, R.E. (2012), 'Exploring Formal and Non-formal Education Practices for Integrated and Diverse Learning Environments in Uganda', International dournal of Diversity in Organizations, Communities and Nations, Vol 11 No 6, 109-121.

OECD (2013), Entrepreneurship at a Glance. OECD Publishing. [Available online] http://dx.doi.org/10.1787/entroprenour_aag-2013-en (accessed 19_duly 2016)

Piperopoulos, P. (2012), 'Could higher education programmes, culture and structure stifle the entrepreneurial intentions of students?', Journal of Small Business and Enterprise Development, Vol 19 No 3, pp 461-483

Pittaway, L., and Cope, J. (2007), 'Entrepreneurship education a systematic review of the evidence', International Small Business Journal, Vol 25 No 5, pp 479-510.

Pittaway, L., Rodriguez Falcon, E., Aiyegbayo, O., and King, A. (2011), 'The role of entrepreneurship elubs and societies in entrepreneurial learning', International Small Business Journal, Vol 29 No 1, pp $37-57$

Rae, D. (2010), 'Universities and enterprise education: responding to the challenges of the new era', Lournal of Small Business and Enterprise Development, Vol 17 No-4, pp 591-606.

Rae, D., and Carswell, M. (2001), 'Towards a conceptual understanding of entrepreneurial learning', Journal of Small Business and Enterprise Development, Vol 8 No 2, pp 150-158.

Sarasvathy, S.D. and Dew, N. (2005), 'Entrepreneurial logics for a technology of foolishness', Scandinavian Journal of Managoment, Vol 21 No 4, pp 385-406.

Saunders, M.N.K., Gray, E.D., and Goregaokar, H. (2013), 'SME innovation and learning: the role of networks and crisis events', European Journal of Training and Development, Vol $38 \mathrm{No}$ 1/2, pp 136-149.

Sharma, P., and Choudhary, A. (2015), 'Learning in Different Educational Settings; Methodological Goncerns', Journal of Humanities and Social Science, Vol $20 \mathrm{No} 4$, pp 18-25.
Formatted: Highlight

Formatted: Highlight

Formatted: Highlight

Formatted: Highlight

Formatted: Highlight

Formatted: Highlight

Formatted: Highlight

Formatted: Highlight

Formatted: Highlight

Formatted: Highlight

Formatted: Highlight

Formatted: Highlight 
Shepherd, D.A., and Douglas, E.J. (1997), Is management oducation developing, or killing, the entrepreneurial spirit, in Proceedings of the 1997 USASBE Annual National Conference 'Entrepreneurship: The Engine of Global Economic Development', San Francisco, Galifornia.

Skule, S. (2004), 'Learning conditions at work: a framework to understand and assess informal learning in the workplace', International Journal of Training and Development, Vol 8 No 1, pp 8-20.

Smith, K. (2015), 'Measuring the impact of enterprise oducation and entrepreneurship support in higher education: Can routinely collected data be of use?', Industry and Higher Education, Vol 29 No 6, pp 493-503.

Souitaris, V., Zerbinati, S., Al-Laham, A. (2007), 'Do entrepreneurship programmes raise entrepreneurial intention of science and engineering students? The effect of learning, inspiration and resources', dournal of Business Venturing, Vol $22 \mathrm{No}-4$, pp $566-591$.

Stam, W., and Elfring, T. (2008), 'Entrepreneurial orientation and new venture performance: The moderating role of intra-and extraindustry social capital', Academy of Management Journal, Vol 51 No 1, pp 97-111.

Stam, W., Arzlanian, S., and Elfring, T. (2014), 'Social capital of entreprenours and small firm performance: A meta-analysis of contextual and methodological moderators', dournal of Business Venturing, Vol 29 No 1 , pp $152-173$.

University of Leeds (2015), Enterprise Impact Report 2014-15. University of Leeds. [Available online] https://www.loeds.ac.uk/downloads/download/90/enterprise_impact_roport_2014-15 (accessed 19 duly 2016)

von Graevenitz, G., Harhoff, D., and Weber, R. (2010), 'The effects of entrepreneurship education', Journal of Economic Behavior \& Organization, Vol 76 No 1, pp 90-112.

Werkins, P. (2010), Recognition of non-formal and informal learning: country practices. [Available online] http://wWw.connect.tsoft.hu/digitaleity/servlet/PublishedFileServlet/AAABEWBX/OECDReport.pdf (accessed 19 July 2016)

Westlund, H., and Adam, F. (2010), 'Social capital and economic performance: A meta-analysis of 65 studies', European Planning Studies, Vol 18 No 6, pp 893-919.

Wostlund, H., Larsson, J.P., and Olsson, A.R. (2014), 'Start-ups and local ontreprenourial social Gapital in the municipalities of Sweden', Regional Studies, Vol 48 No 6, pp 974-994.
Formatted: Highlight

Formatted: Highlight

Formatted: Highlight

Formatted: Highlight

Formatted: Highlight

Formatted: Highlight

Formatted: Highlight

Formatted: Highlight

Formatted: Highlight

Formatted: Highlight

Formatted: Highlight 
Young, L. (2014), Enterprise for All. The relevance of enterprise in education. Department for Business, Innovation \& Skills and Prime Minister's Office. UK. [Available online] https://ww.gov.uk/government/uploads/system/uploads/attachment_data/file/338749/Enterprisefo rAll-lowres-200614.pdf (accessed 19 July 2016)
Formatted: Highlight

Formatted: English (U.K.) 
Figure 1. Leeds interviewees story lines.

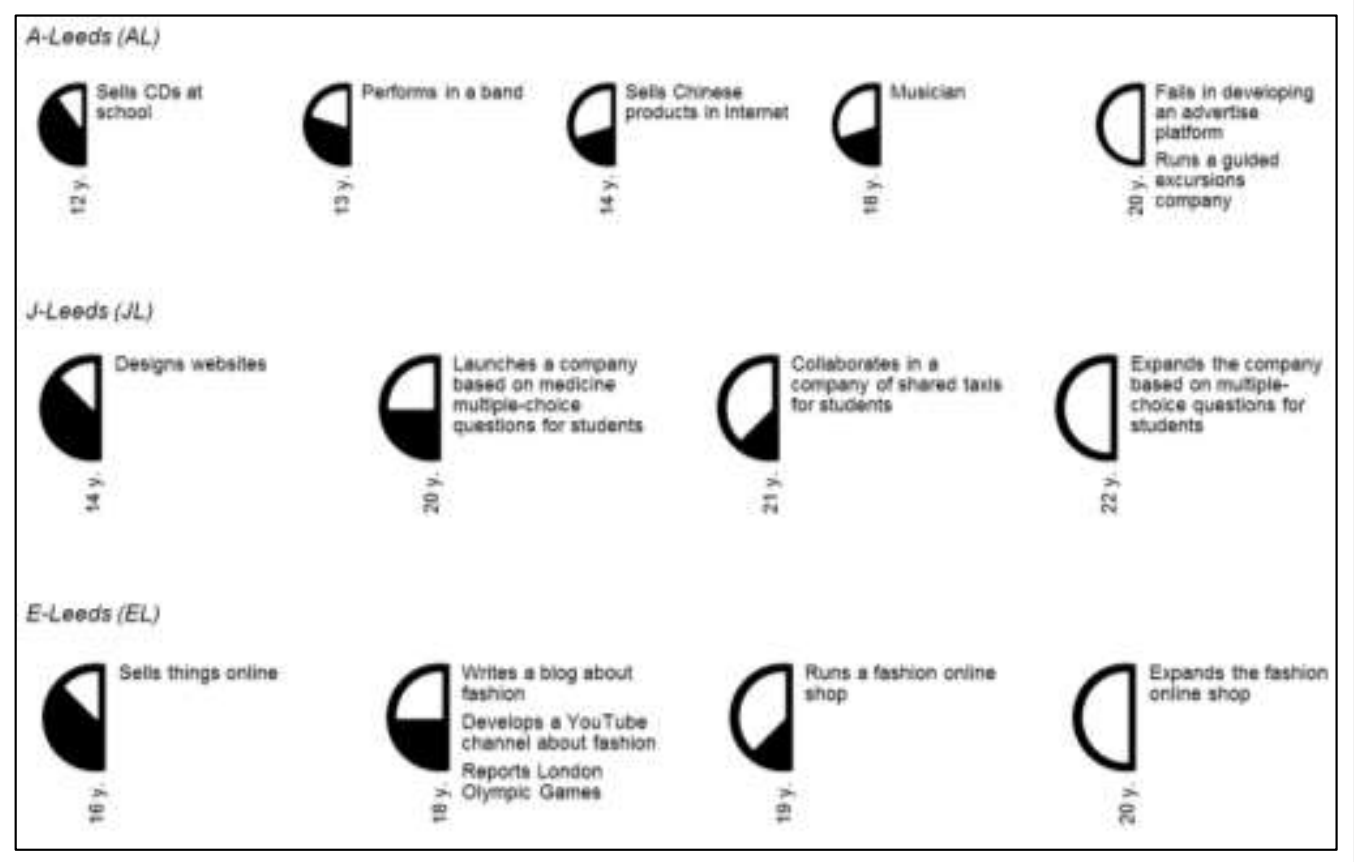

Note: colours within the shapes represent the approximate proportion of formal and informal networks in each entrepreneurial activity: white colour represents the formal network and black colour represents the informal network. Percentages of formal and informal networks were taken during the interviews and represented in graphs using Microsoft Excel. Then, the whole story lines diagrams were drawn with Microsof PowerPoint. 
Figure 2. Chalmers interviewees story lines.

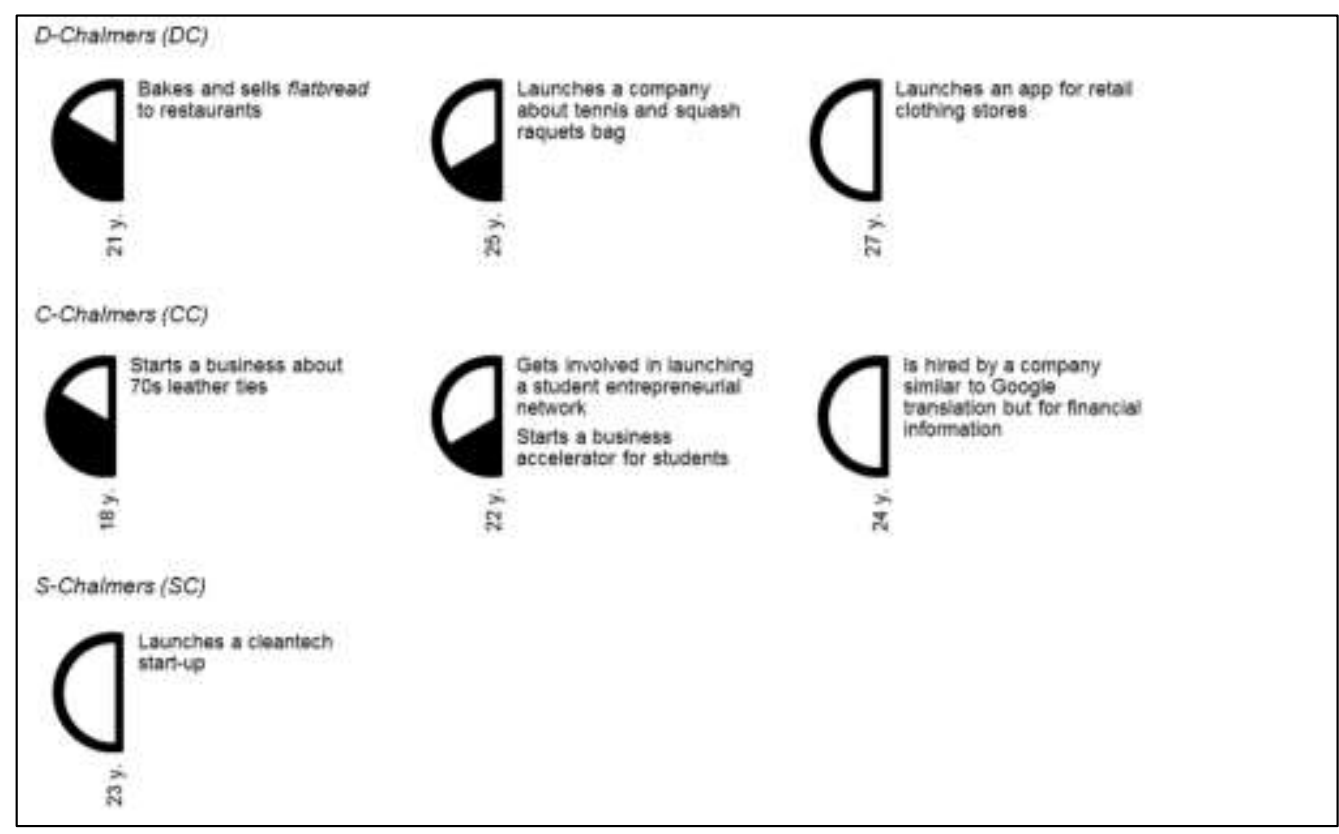

Note: colours within the shapes represent the approximate proportion of formal and informal networks in each entrepreneurial activity: white colour represents the formal network and black colour represents the informal network. Percentages of formal and informal networks were taken during the interviews and represented in graphs using Microsoft Excel. Then, the whole story lines diagrams were drawn with Microsof PowerPoint. 